\title{
Organic Waste Processing Using Molten Salt Oxidation
}

\author{
M.G. Adamson \\ P.C. Hsu \\ D.L. Hipple \\ K.G. Foster \\ R.W. Hopper \\ T.D. Ford
}

This paper was prepared for submittal to the 1998 Euchem Conference on Molten Salts

Porquerolles, France

June 27-July 3, 1998

March 1998

This is a preprint of a paper intended for publication in a journal or proceedings. Since changes may be made before publication, this preprint is made available with the understanding that it will not be cited or reproduced without the permission of the author. 


\section{DISCLAIMER}

This document was prepared as an account of work sponsored by an agency of the United States Government. Neither the United States Government nor the University of California nor any of their employees, makes any warranty, express or implied, or assumes any legal liability or responsibility for the accuracy, completeness, or usefulness of any information, apparatus, product, or process

disclosed, or represents that its use would not infringe privately owned rights. Reference herein to any specific commercial product, process, or service by trade name, trademark, manufacturer, or otherwise, does not necessarily constitute or imply its endorsement, recommendation, or favoring by the United States Government or the University of California. The views and opinions of authors expressed herein do not necessarily state or reflect those of the United States Government or the University of California, and shall not be used for advertising or product endorsement purposes. 


\title{
Organic Waste Processing using Molten Salt Oxidation
}

\author{
Martyn G. Adamson, Peter C. Hsu, David L. Hipple, \\ Kenneth G. Foster, Robert W. Hopper, and Timothy D. Ford \\ Lawrence Livermore National Laboratory \\ P.O. Box 808 \\ Livermore, CA 94551-0808
}

\begin{abstract}
Molten Salt Oxidation (MSO) is a thermal means of oxidizing (destroying) the organic constituents of mixed wastes, hazardous wastes, and energetic materials while retaining inorganic and radioactive constituents in the salt. For this reason, MSO is considered a promising alternative to incineration for the treatment of a variety of organic wastes. The U. S. Department of Energy's Office of Environmental Management (DOE/EM) is currently funding research that will identify alternatives to incineration for the treatment of organic-based mixed wastes. (Mixed wastes are defined as waste streams which have both hazardous and radioactive properties.) One such project is Lawrence Livermore National Laboratory's Expedited Technology Demonstration of Molten Salt Oxidation (MSO). The goal of this project is to conduct an integrated demonstration of MSO, including off-gas and spent salt treatment, and the preparation of robust solid final forms. Livermore National Laboratory (LLNL) has constructed an integrated pilot-scale MSO treatment system in which tests and demonstrations are presently being performed under carefully controlled (experimental) conditions. The system consists of a MSO process vessel with dedicated off-gas treatment, a salt recycle system, feed preparation equipment, and equipment for preparing ceramic final waste forms. In this paper we describe the integrated system and discuss its capabilities as well as preliminary process demonstration data. A primary purpose of these demonstrations is to identify the most suitable waste streams and waste types for MSO treatment.
\end{abstract}

\section{INTRODUCTION}

Molten Salt technology is not new. Rockwell used the process over 20 years ago for coal gasification. During that period, they also demonstrated the effectiveness of molten salt for destroying hazardous organics such as PCBs and TCE. Extensive experience on laboratory-, bench-, and pilot-scale MSO units has been obtained at ETEC, LLNL, ORNL, and Rockwell since the technology's introduction [1,2,3]. Within the last five years, molten salt has been demonstrated as an effective method for the destruction of mixed waste oils and energetic materials [4]. Approximately 2 years ago, the U.S. Department of Energy's Office of Environmental Management (DOE/EM) decided that the MSO technology was sufficiently mature to demonstrate as an integrated pilot-scale treatment system. The system described here was designed and built in approximately 1 1/2 years, and it is now operational.

MSO is a robust thermal treatment process for destroying organic waste. In this process, organic-containing wastes are injected with a stoichiometric excess of oxidant air under a pool of molten carbonate salts at temperatures between $700-950^{\circ} \mathrm{C}$. Flameless oxidation takes place within the salt bath converting the organic components of the waste into $\mathrm{CO}_{2}$, and water. The product off-gas leaving the vessel is treated to remove any entrained salt particulate and essentially all water vapor before being discharged to the facility off-gas system. Halogens and heteroatoms such as sulfur are converted into acid gases, which are then "scrubbed" and trapped in the salt in forms such as $\mathrm{NaCl}$ and $\mathrm{Na}_{2} \mathrm{SO}_{4}$. Using sodium carbonate in the processor, this process occurs according to the reactions shown in Equations 1, 2, 3, and 4, where $\mathrm{X}$ represents generic halogens: 


$$
2 \mathrm{C}_{\mathrm{a}} \mathrm{H}_{\mathrm{b}}+(2 \mathrm{a}+\mathrm{b} / 2) \mathrm{O}_{2}---->2 \mathrm{aCO}_{2}+\mathrm{bH}_{2} \mathrm{O}
$$

For nitrogen-bearing organic wastes,

$$
\mathrm{C}_{\mathrm{a}} \mathrm{H}_{\mathrm{b}} \mathrm{N}_{\mathrm{c}}+(\mathrm{a}+\mathrm{b} / 4) \mathrm{O}_{2}---->\mathrm{aCO}_{2}+\mathrm{b} / 2 \mathrm{H}_{2} \mathrm{O}+\mathrm{c} / 2 \mathrm{~N}_{2}
$$

For halogenated organic wastes,

$$
\mathrm{C}_{\mathrm{a}} \mathrm{H}_{\mathrm{b}} \mathrm{X}_{\mathrm{c}}+\mathrm{c} / 2 \mathrm{Na}_{2} \mathrm{CO}_{3}+(\mathrm{a}+(\mathrm{b}-\mathrm{c}) / 4) \mathrm{O}_{2}---->(\mathrm{a}+\mathrm{c} / 2) \mathrm{CO}_{2}+\mathrm{b} / 2 \mathrm{H}_{2} \mathrm{O}+\mathrm{cNaX}
$$

For sulfur-containing organic wastes,

$$
\mathrm{C}_{\mathrm{a}} \mathrm{H}_{\mathrm{b}} \mathrm{S}_{\mathrm{c}}+\mathrm{cNa}_{2} \mathrm{CO}_{3}+(\mathrm{a}+\mathrm{b} / 4+3 \mathrm{c} / 2) \mathrm{O}_{2}---->(\mathrm{a}+\mathrm{c}) \mathrm{CO}_{2}+\mathrm{b} / 2 \mathrm{H}_{2} \mathrm{O}+\mathrm{cNa}_{2} \mathrm{SO}_{4}(4)
$$

Other non-oxidizable inorganic constituents, heavy metals, and radionuclides are held captive in the salt, either as metals or oxides, and most are easily separated for disposal.

MSO has several advantages over incineration. The large thermal mass of the molten salt provides a stable heat-transfer medium that resists thermal surges and ensures temperature uniformity and is therefore able to tolerate rapid process fluctuations. Flame-outs are completely avoided, since MSO is a non-flame process that proceeds by catalytic liquid-phase oxidation reactions. MSO generates less off-gas than incineration, since it does not require supplemental fuel to sustain a flame. Operation of the MSO system is at temperatures hundreds of degrees lower than flame combustion temperatures, which, among other things, minimizes emissions of the radioactive materials from mixed wastes. Acid gases are "scrubbed" by the alkali salts, eliminating the need for a wet off-gas scrubbing system.

\section{DESCRIPTION OF THE MSO FACILITY AT LLNL}

The LLNL's MSO facility, shown in the photo and in Fig. 1, consists of several subsystems. It includes a process vessel, an off-gas treatment system, a salt recycle system, feed preparation equipment, as well as a ceramic final waste forms immobilization system. The feed preparation area includes waste receiving drums, a centrifuge for solid liquid separation, and a shredder for size-reducing "soft" solid wastes such as paper, rags, gloves, booties, etc. The waste is fed to the reaction vessel along with oxidant air using a top-feed injection system designed for solid and liquid waste streams at throughputs up to $7 \mathrm{~kg} / \mathrm{hr}$ for chlorinated solvents. Product gases exiting the vessel are then treated in the off-gas system to remove entrained salt particulates, water vapor, and traces of gas species such as $\mathrm{CO}$ and $\mathrm{NO}_{\mathrm{x}}$. As waste is injected into the MSO vessel, residues of inorganic components build up in the salt bed which necessitates periodic removal of salt and replenishment with fresh salt to maintain process efficiency. Because many of the metals and/or radionuclides captured in the salt are hazardous and/or radioactive, without further treatment the removed spent salt would create a large secondary waste stream. A salt recycle system is needed to segregate these materials to minimize the amount of secondary waste, and to reduce the consumption of fresh salt $[5,7]$. The segregated inorganic residues are then encapsulated in a ceramic matrix for final disposal. Each subsystem is described below.

\section{Process Vessel/Off-gas System}

Figure 2 shows the process vessel and the off-gas system. The vessel is 2.74 meter tall and is $38.1 \mathrm{~cm}$ inside diameter over the top half and $29.8 \mathrm{~cm}$ inside diameter over the bottom half, with a $30.5 \mathrm{~cm}$ long, tapered transition zone in between. The normal salt load is $160 \mathrm{~kg}$ and fills the vessel to the bottom of the transition zone when quiet. The freeboard area of the vessel above the salt level provides a disengagement zone for salt spray to separate from the off-gas before it exits. There are baffles in this region to assist in separating the salt spray. The air and 


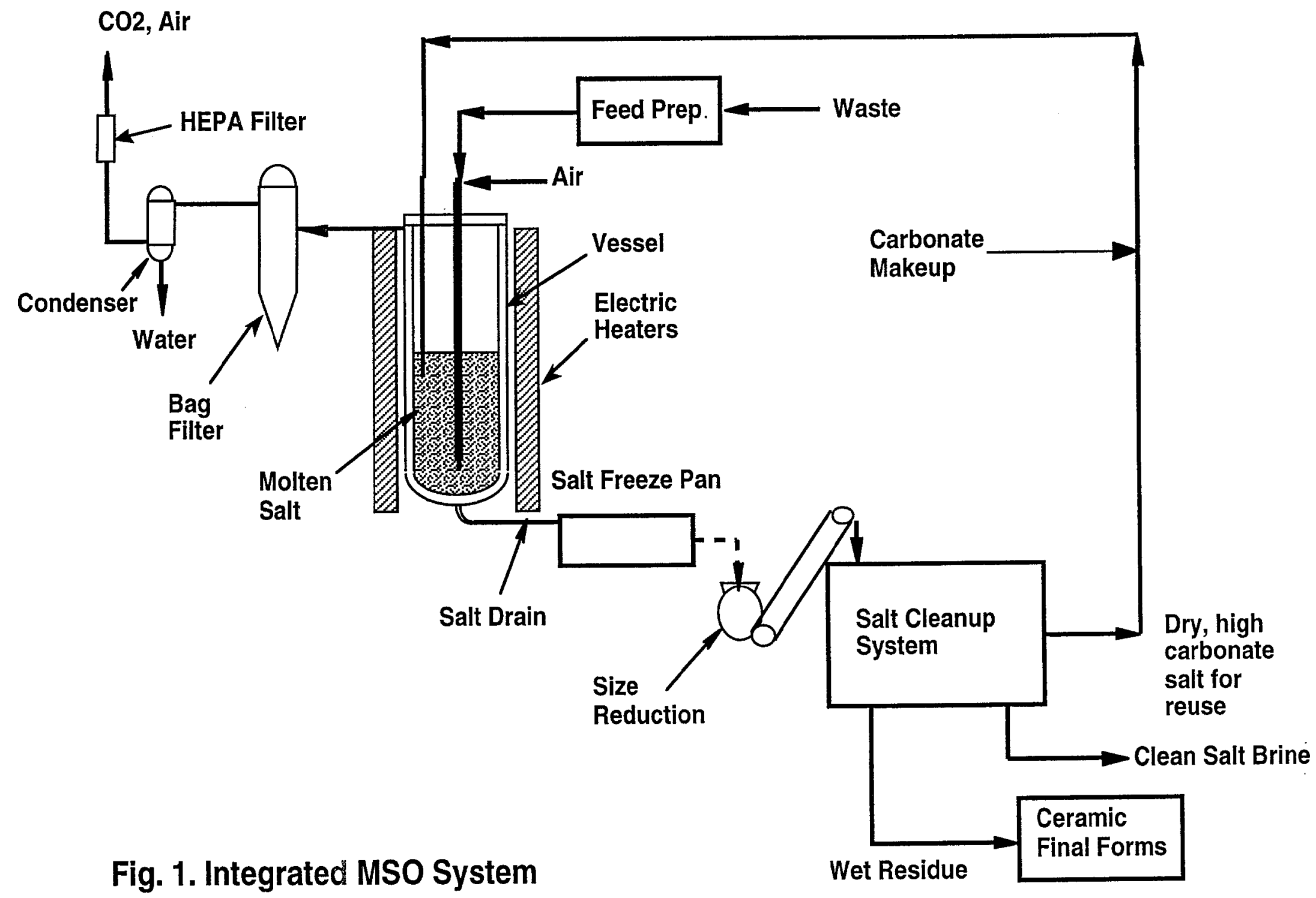




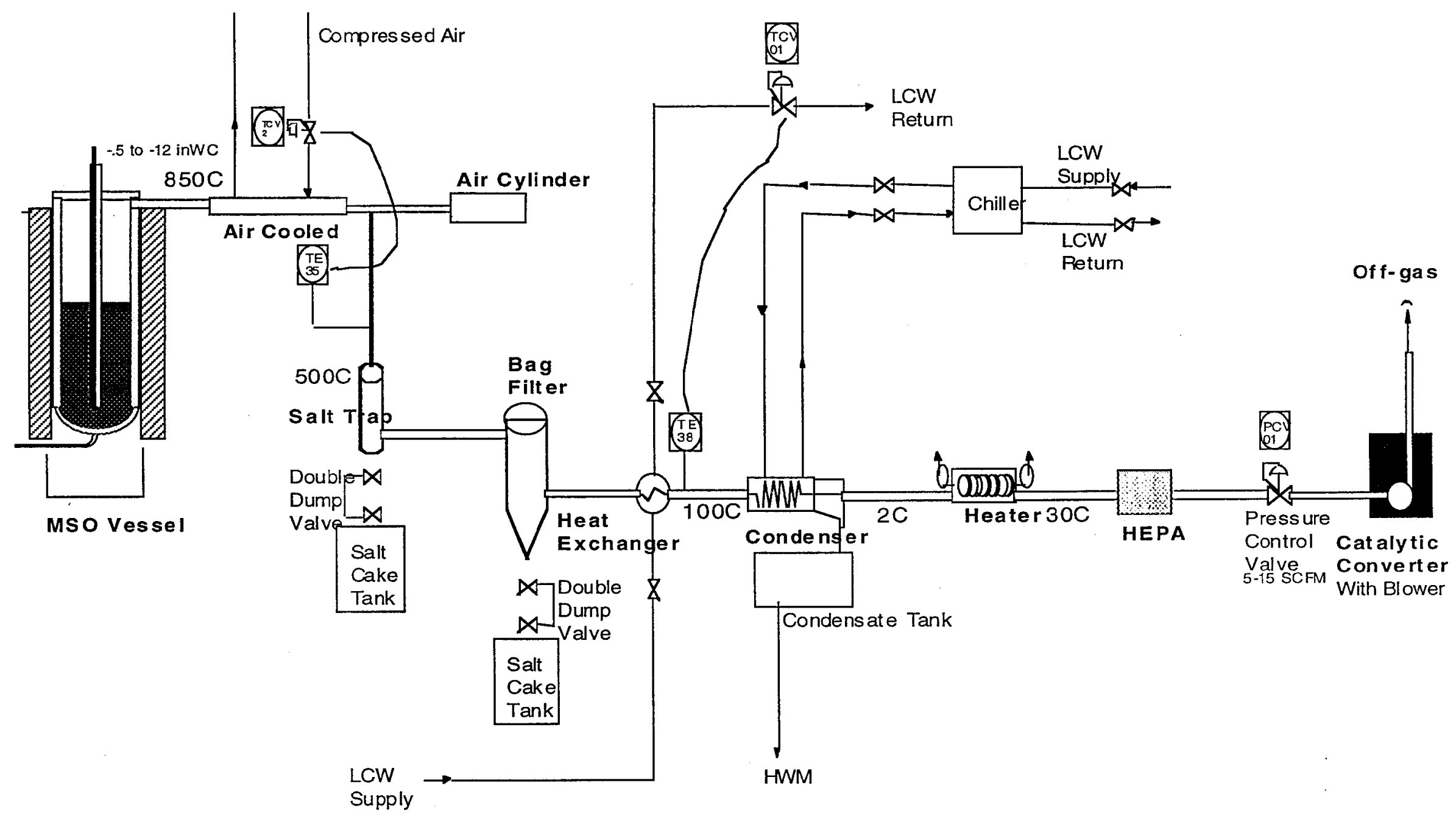

Fig. 2 Process Vessel and Off-gas System 
feed material enter through an injector lance extending through the vessel cover to the bottom of the vessel. The injector is insulated and air cooled to keep the feed temperature low until it leaves the injector and contacts the molten salt. The vessel is fabricated from $1.27 \mathrm{~cm}$ thick Inconel $600^{\circledR}$ material. Corrosion tests at LLNL have shown an acceptable corrosion rate for Inconel $600^{\circledR}$ in $\mathrm{Na}_{2} \mathrm{CO}_{3}$ and $\mathrm{NaCl}$ salt mixtures at operating temperature [6]. The most severe corrosion occurs at high $\mathrm{NaCl}$ contents. The vessel is protected against overpressure by placing close limitations on maximum feed rates, by closely monitoring the offgas system to prevent build up of salt deposits that may cause plugging, and by a rupture disk on a dedicated vessel nozzle. The rupture disc is a low pressure disk that discharges into a separate exhaust vent stack. The vessel is held from the top and mounts on a free standing structural support stand. The heaters are radiant electric type and are made up of two major subassemblies: one assembly covering the top half of the vessel and a second subassembly covering the bottom half. The heaters are separately supported from the vessel support stand. The vessel also has a salt drain pipe extending from the bottom of the vessel to outside the heated zone. The vessel temperature is maintained by the control system. When exothermic materials are being fed, the vessel must be cooled to prevent overheating. A blower is provided for this which blows ambient air though the annular space between the heaters and the vessel wall.

The off-gas exiting the vessel is first cooled to $500^{\circ} \mathrm{C}$ by the gas-to-air cooler. The gas-toair cooler consists of two concentric pipes with an annular gap between them. Compressed air flows through the annular gap and cools the gas flowing through the inner pipe. As the gas stream cools, the entrained salt cools and sticks to the inner pipe wall. Salt buildup is removed by a wire brush on the end of a rod that is driven and retracted by the air cylinder. The dislodged salt falls into the vessel on the forward stroke and falls into the salt trap on the reverse stroke. The smaller entrained particles are captured in the pulsating, self-cleaning ceramic filter. The ceramic filter captures particles $\geq 0.5$ micrometers in size and can withstand gas temperatures up to $700^{\circ} \mathrm{C}$. Six silicon carbide filter elements are pulsed with compressed air to remove caked-on salt when the pressure drop across the elements reaches $2.74 \mathrm{kPa}$ (11 inches water). The captured salt in the salt trap and ceramic filter is removed by cycling double dump valves that allow the salt to fall into a drum below them. The double dump valves are used to isolate the negative system pressure from the atmospheric drum pressure. The gas is kept at about $300^{\circ} \mathrm{C}$ to ensure that the gas is well above the dewpoint $\left(50^{\circ} \mathrm{C}\right)$ to avoid any water condensation and that the salt remains dry. The filtered off-gas is then cooled to $100^{\circ} \mathrm{C}$ by a shell and tube heat exchanger using low conductivity water. The moisture is removed when the gas is cooled to $2^{\circ} \mathrm{C}$ by the condenser using propylene glycol from a chiller. The gas is then heated to $30^{\circ} \mathrm{C}$ by an electrical heater to ensure dry gas enters the HEPA filter. The HEPA filter serves two purposes. It acts as a pre-filter for the catalytic converter and a barrier for remaining particles in the offgas. Thus no salt particles escape the process off-gas system. The catalytic converter is designed to abate 50,000 ppm of $\mathrm{CO}$ and $30,000 \mathrm{ppm}$ of $\mathrm{NO}_{\mathrm{x}}$. It converts $\mathrm{CO}$ into $\mathrm{CO}_{2}$ in a catalyst bed at elevated temperatures. It also is equipped with an ammonia injection system that converts $\mathrm{NO}_{\mathrm{X}}$ into $\mathrm{N}_{2}$ and $\mathrm{H}_{2} \mathrm{O}$ by selective catalytic reduction. The off-gas leaving the catalytic converter is very clean and is exhausted to a building stack via a ducting system.

\section{Salt Recycle System}

The salt recycle system, shown as a flow diagram in Fig 3, receives spent salts from the MSO vessel and off-gas system. The size of spent salt is reduced to approximately $6.3 \mathrm{~mm}$ inside an enclosure with the aid of hand tools, air-power tools, and a crusher. Small salt particles are then transferred to tank T-101 by a spiral conveyor. Salt samples will be taken during salt crushing for analysis. Salt dissolution will be performed in tank T-101 using either deionized or clean recycled water. Most of mineral residues and ashes will precipitate as hydroxides and oxides during the dissolution step. Chemical reagents such as sodium hydroxide, hydrochloric acid, and dithionite will be used at various stages of the process to adjust $\mathrm{pH}$ and/or facilitate metals removal. Reagents such as alum $\left[\mathrm{Al}_{2}\left(\mathrm{SO}_{4}\right)_{3}\right]$ and activated silica will be added to facilitate 


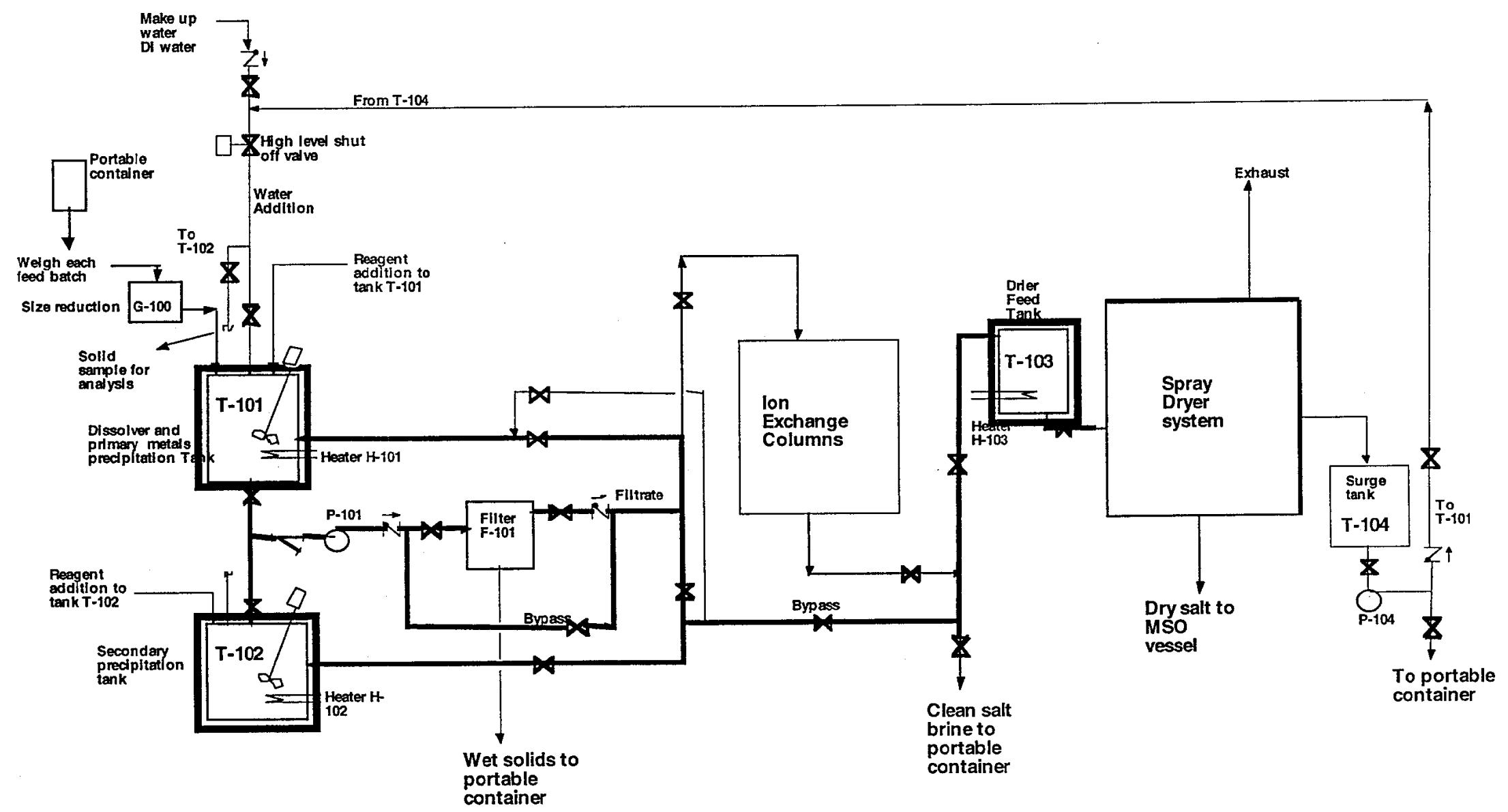

Fig. 3. Salt Recycle System flow diagram 
the coagulation \& precipitation process to avoid an excessive holding time in the dissolver tank. These reagents can be fed into the T-101 or T-102 by metering pumps or by opening the hatch. Once precipitated, these solids can then be removed by pumping the solution through F-101. The filter has a filter element of 1 micron and will efficiently remove solid particles from the salt solution. The filter element may be pre-coated with a thin layer of diatomaceous earth to facilitate the filtration process. At various stages, the filter cake will have to be removed by opening the filter vessel and relocating the filter cartridge into the wash-off area inside the enclosure. Air and water will be used to assist the cake removal. The wet cakes are then sent to the Final Forms for immobilization. The filtration operation is performed inside an enclosure. After metals precipitation, the salt solution will go to a spray dryer, ion exchange columns, and/or portable containers, depending on the concentrations of carbonate and radionuclides. If the spent salt contains a high level of carbonate, then the solution will be pumped to T-103 for spray drying. The spray-dried salt is then sent back to the MSO vessel for reuse. If it contains low levels of carbonate and traces of uranium and thorium, then the salt solution will be pumped to the ion exchange columns E-101/E-102 for removal of radionuclides. In some instances, the salt solution will be pumped to portable containers and shipped to Hazardous Waste Management (HWM) of LLNL.

\section{Ceramic Final Forms}

The wet filter cake produced by the salt recycle system will contain residues from the MSO process itself, typically deriving from a variety of input waste, and compounds introduced by the salt recycle process. In addition to metals and oxides, there may be some carbonates, phosphates, sulfates, sulfides, borides, carbides and nitrides. Overall, LLNL residues are expected to be dominated by $\mathrm{Si}, \mathrm{Al}, \mathrm{Mg}, \mathrm{Zn}, \mathrm{Ca}$ and $\mathrm{Fe}$. Any of a wide variety of elements may be present in minor or trace amounts. The ceramic final waste form must immobilize the hazardous and radioactive elements present; both the ceramic material and the process to make it must be adaptable to the variable composition of the filter cake; and a high waste loading is desirable. The ceramic is intended to satisfy federal and California leach resistance standards; see Refs. 13-15. The ceramic material comprises several crystalline phases. They were chosen because (1) they can be fabricated as a durable ceramic using standard and economical ceramic processing methods; and (2) because they can incorporate, either as major constituents or by ion substitution, all of the dominant elements just mentioned, and most of the hazardous and radioactive elements of concern. A recipe is calculated for each residue batch (i.e., filter cake), based on its elemental content, and waste loadings are optimized by blending residue batches.

The main equipment items in the Final Forms sub-system are as follows:

1. A standard fume hood for weighing and mixing powders.

2. A recirculating attrition mill for wet blending and comminuting the formulation.

3. A rotary calciner (tube ID $10 \mathrm{~cm}$, heated length $1.2 \mathrm{~m}, 3$-zone, $900^{\circ} \mathrm{C}$ maximum) for drying the slurry and calcining the dried mixture. It is equipped with an integral cooling section, with hammers and a scraper (to deal with any caking), feed and discharge systems incorporating airtight seals, air input and offgas removal systems, and a simple offgas conditioning system.

4. A rotary granulator in which the calcined powder is formed into $\sim 1 \mathrm{~mm}$ granules.

5. An automatic pellet press (maximum force $\sim 36 \mathrm{KN}$, maximum rate 150 strokes $/ \mathrm{min}$ ) for forming the "green" pellets. This press is a sliding-anvil design, which is virtually dust-free.

6. A large tube furnace $\left(1300^{\circ} \mathrm{C}, 3\right.$-zone, $15 \mathrm{~cm} \mathrm{ID,} 91 \mathrm{~cm}$ long), with a retort and programmercontrollers, for sintering the pellets. 
7. A small tube furnace $\left(1300^{\circ} \mathrm{C}, 5\right.$-zone, $7.6 \mathrm{~cm} \mathrm{ID,} 91 \mathrm{~cm}$ long), with a retort and programmercontrollers, for process-control test sintering.

The system also includes a variety of quality-control, process-control and lab-scale processing equipment. Control is local to each equipment item; process monitoring and data collection is direct to the Final Forms computer. Suitable hazards controls will be in place. In particular, the powder processing steps are conducted in closed equipment or in fume hoods to avoid dispersion of the powders; and monitoring equipment will measure the level of radioactivity and the particle concentration in the work stations and area. All exhaust gases pass through local HEPA filters prior to entering the building exhaust system. The only unattended operation is sintering. The system is capable of producing $\sim 2 \mathrm{Kg}$ of ceramic waste form per 8-h working day, in the form of cylindrical pellets approximately $9 \mathrm{~mm}$ dia $\times 7 \mathrm{~mm}$ tall. The production capacity is presently limited by the sintering step; it could be doubled by adding a second tube furnace. A functional flow diagram for the ceramic waste form process is illustrated in Fig. 4.

\section{EXPERIMENTS AND RESULTS}

This integrated system was designed and engineered based on laboratory experience with a smaller engineering-scale unit and extensive laboratory development on salt recycle and final forms preparation. This section reports some experimental results.

Process Vessel/Off-gas System

A smaller engineering development unit (EDU) was built in 1995 with the principal goal of verifying the MSO technology with several model feeds at a meaningful engineering scale before an integrated pilot scale facility was designed and built. It became operational in the Summer of 1995. It was run for several hundred hours from Summer 95 to Spring 96 with several model feeds and valuable technical data were obtained. Several species such as $\mathrm{O}_{2}, \mathrm{CO}, \mathrm{CO}_{2}, \mathrm{NO}_{\mathrm{x}}$, and TOC (total organic carbon) in the off-gas were monitored continuously during the course of experiment I. Table I. shows average concentrations of several species in the off-gas at various operation temperatures and chlorine levels in the salt melt. Concentrations of $\mathrm{CO}$ and $\mathrm{NO}_{\mathrm{x}}$ decrease as temperature increases. $\mathrm{Cl}$ level in the salt melt seems to have a minor effect on the concentrations of $\mathrm{CO}$ and $\mathrm{NO}_{\mathrm{x}}$, although its effect is not as profound as that of temperature. Concentration of THC is very small in each case, an indication of high process efficiency. Process efficiency is defined as

$$
\text { Process Efficiency }=\left(1-\frac{\dot{\mathrm{M}}_{\mathrm{c}, \text { out }}}{\dot{\mathrm{M}}_{\mathrm{c}, \text { in }}}\right) * 100 \%
$$

where $\dot{M}_{c, \text { in }}$ and $\dot{M}_{c}$,out are total organic carbon in the feed and in the off-gas, respectively, $g$ organic carbon/min. Oxidation is complete when the process efficiency reaches $100 \%$ (i.e. no organic carbon in the off-gas). Table I indicates that the process efficiency was at or greater than $99.9999 \%$.

The integrated MSO system has been operational since December 1997. The system has been demonstrated with several surrogate organics including toluene, mineral oil, ethylene glycol, pyridine, dimethyl sulfoxide, trimethyl phosphate, trichloroethylene, and Freon with very high process efficiency. An eight hour test with toluene was performed recently to demonstrate longer term stability of the system. Figure 5 and Table II show the results of this run. Total organic carbon in the off gas was less than $1.0 \mathrm{ppm}$, an indication of very high process efficiency. $\mathrm{NO}_{\mathrm{x}}$ concentration was about $60 \mathrm{ppm}$, probably due to traces of nitrogen-bearing 


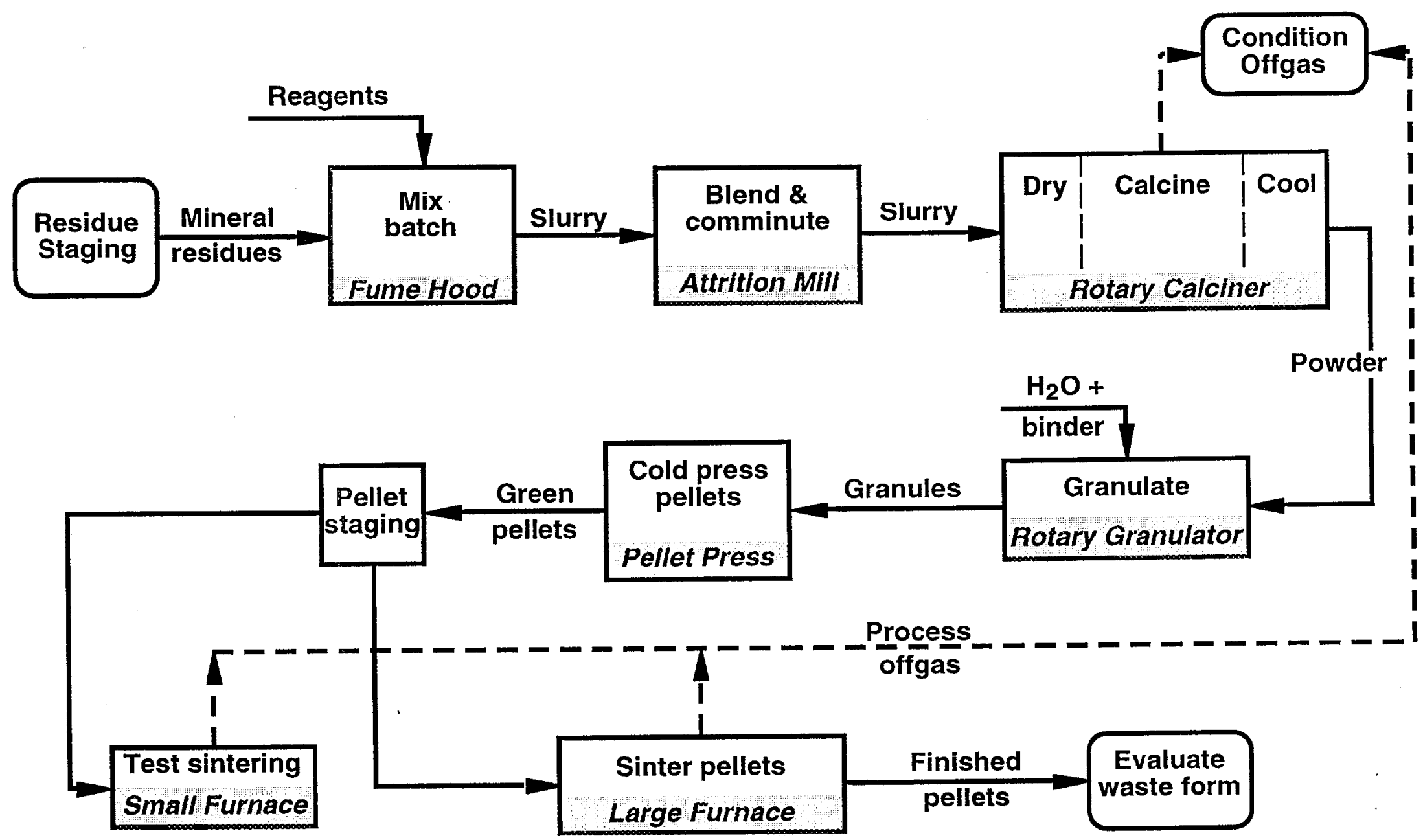

Figure 4. Ceramic waste form process functional flow diagram.

Wastewater streams generated are not shown. 
Table I Effect of Chloride Level on the Quality of Off-gas

Mineral Oil/Toluene as model Feed, at Vs $=0.3 \mathrm{~m} / \mathrm{s}$ and $30 \%$ Excess Air

\begin{tabular}{|c|c|c|c|c|c|c|c|c|}
\hline $\begin{array}{c}\text { C1 } \\
\text { Level }\end{array}$ & $\begin{array}{c}\text { Target } \\
\mathrm{T}\left({ }^{\circ} \mathrm{C}\right)\end{array}$ & $\% \mathrm{O} 2$ & $\mathrm{ppm} \mathrm{CO}$ & $\% \mathrm{CO} 2$ & $\mathrm{ppm} \mathrm{NOx}$ & $\begin{array}{l}\text { Organic } \\
\text { Carbon } \\
\text { in the } \\
\text { Off-gas } \\
\mathrm{g} / \mathrm{min}\end{array}$ & $\begin{array}{c}\text { Process } \\
\text { Efficiency } \%\end{array}$ \\
\hline 0 & 880 & 4.50 & 26.23 & 12.16 & 123.71 & 0.01 & $6.8 \times 10^{-7}$ & $>99.9999$ \\
\hline 0 & 925 & 4.82 & 23.29 & 12.22 & 55.76 & 0.02 & $1.4 \times 10^{-6}$ & $>99.9999$ \\
\hline 0 & 950 & 4.76 & 20.47 & 12.33 & 59.35 & 0.06 & $4.1 \times 10^{-6}$ & $>99.9999$ \\
\hline 12.9 & 850 & 4.25 & 294.33 & 12.28 & 147.30 & 0.11 & $7.5 \times 10^{-6}$ & 99.9999 \\
\hline 12.9 & 900 & 4.43 & 122.91 & 12.05 & 94.18 & 0.08 & $5.4 \times 10^{-6}$ & $>99.9999$ \\
\hline 12.9 & 950 & 4.31 & 51.11 & 12.39 & 79.02 & 0.09 & $6.1 \times 10^{-6}$ & $>99.9999$ \\
\hline 43.3 & 850 & 5.22 & 205.07 & 11.89 & 241.62 & 0.10 & $6.8 \times 10^{-6}$ & $>99.9999$ \\
\hline 43.3 & 900 & 5.31 & 282.64 & 11.51 & 88.38 & 0.11 & $7.5 \times 10^{-6}$ & 99.9999 \\
\hline 43.3 & 950 & 5.24 & 160.48 & 12.32 & 78.50 & 0.11 & $7.5 \times 10^{-6}$ & 99.9999 \\
\hline 62.8 & 800 & 4.56 & 936.26 & 11.54 & 250.07 & 0.16 & $1.1 \times 10^{-5}$ & 99.9999 \\
\hline 62.8 & 850 & 4.52 & 732.50 & 11.52 & 126.52 & 0.17 & $1.2 \times 10^{-5}$ & 99.9999 \\
\hline 62.8 & 900 & 4.45 & 475.35 & 11.55 & 108.87 & 0.13 & $8.8 \times 10^{-6}$ & 99.9999 \\
\hline 62.8 & 950 & 4.39 & 161.75 & 12.20 & 106.82 & 0.11 & $7.5 \times 10^{-6}$ & 99.9999 \\
\hline
\end{tabular}

*Notes: average values during the course of experiment; organic carbon feed rate $7.8 \mathrm{~g} / \mathrm{min}$ 
Table II 8 Hour Run with Toluene

Run Condition: Organic feed rate $1.2 \mathrm{Kg}$ Toluene/hr, $30 \%$ excess air, salt at $950^{\circ} \mathrm{C}$

\begin{tabular}{|c|c|c|c|c|c|c|}
\hline & \multicolumn{7}{|c|}{ Off-Gas Concentration* } \\
\hline Time & $\begin{array}{c}\mathrm{CO}_{2} \\
\%\end{array}$ & $\begin{array}{c}\mathrm{O}_{2} \\
\%\end{array}$ & $\begin{array}{c}\mathrm{CO} \\
\mathrm{ppm}\end{array}$ & $\begin{array}{c}\mathrm{NO}_{\mathrm{x}} \\
\mathrm{ppm}\end{array}$ & $\begin{array}{c}\mathrm{SO}_{\mathrm{x}} \\
\mathrm{ppm}\end{array}$ & $\begin{array}{c}\text { THC** } \\
\mathrm{ppm}\end{array}$ \\
\hline $9: 00$ & 9.10 & 10.22 & 5.5 & 73 & 0 & 0.40 \\
\hline $10: 00$ & 8.92 & 9.89 & 5.6 & 66 & 0 & 0.34 \\
\hline $11: 00$ & 8.66 & 10.19 & 5.3 & 62 & 0 & 0.43 \\
\hline $12: 00$ & 8.75 & 10.01 & 5.6 & 63 & 0 & 0.46 \\
\hline $13: 00$ & 8.70 & 9.80 & 8.2 & 60 & 0 & 0.59 \\
\hline $14: 00$ & 8.60 & 9.90 & 8.7 & 59 & 0 & 0.72 \\
\hline 15.00 & 8.50 & 9.97 & 8.7 & 59 & 0 & 0.73 \\
\hline $16: 00$ & 8.57 & 9.93 & 8.2 & 59 & 0 & 0.86 \\
\hline
\end{tabular}

*off-gas analyzers drifted $\pm 2 \%$ full-scale per day

** corrected values

organic compounds in toluene. Our experience with EDU operation indicates that $45 \%$ of nitrogen in an organic compound would convert to $\mathrm{NO}_{\mathrm{x}} . \mathrm{SO}_{\mathrm{x}}$ and $\mathrm{CO}$ levels were very low. The integrated system will be equipped with sample collection trains for comprehensive analysis of off-gas species, including volatile and semi-volatile organics in the Spring of 1998. LLNL has a comprehensive test plan to conduct an integrated demonstration in 1998. This demonstration will include the destruction of organic liquids and organic solids with maximum dimensions on the order of $3 \mathrm{~mm}$ (dictated by the injector). Candidate DOE low-level mixed waste streams for eventual treatment with the MSO technology include spent solvents, oils, and other organic liquids; plutonium contaminated leaded gloves; spent ion exchange resins, and spent activated carbon.

\section{Salt Recycle Process}

Figure 6 shows the process flowsheet of the salt recycle system. It includes salt dissolution, $\mathrm{pH}$ adjustment, chemical reduction, coagulation, filtration, ion exchange, and drying. The process uses dithionite to vary the oxidation states of several metals in order to suppress their solubilities in water. This process allows secondary wastes to be reduced to less than 5\% of the original salt weight. It is a low temperature, aqueous process that has been successfully demonstrated in the laboratory several times. The salt recycle process was also demonstrated successfully with EDU spent salt. X-ray fluorescence was used to determine the elemental composition of the spent salt, which is shown in Table III. 


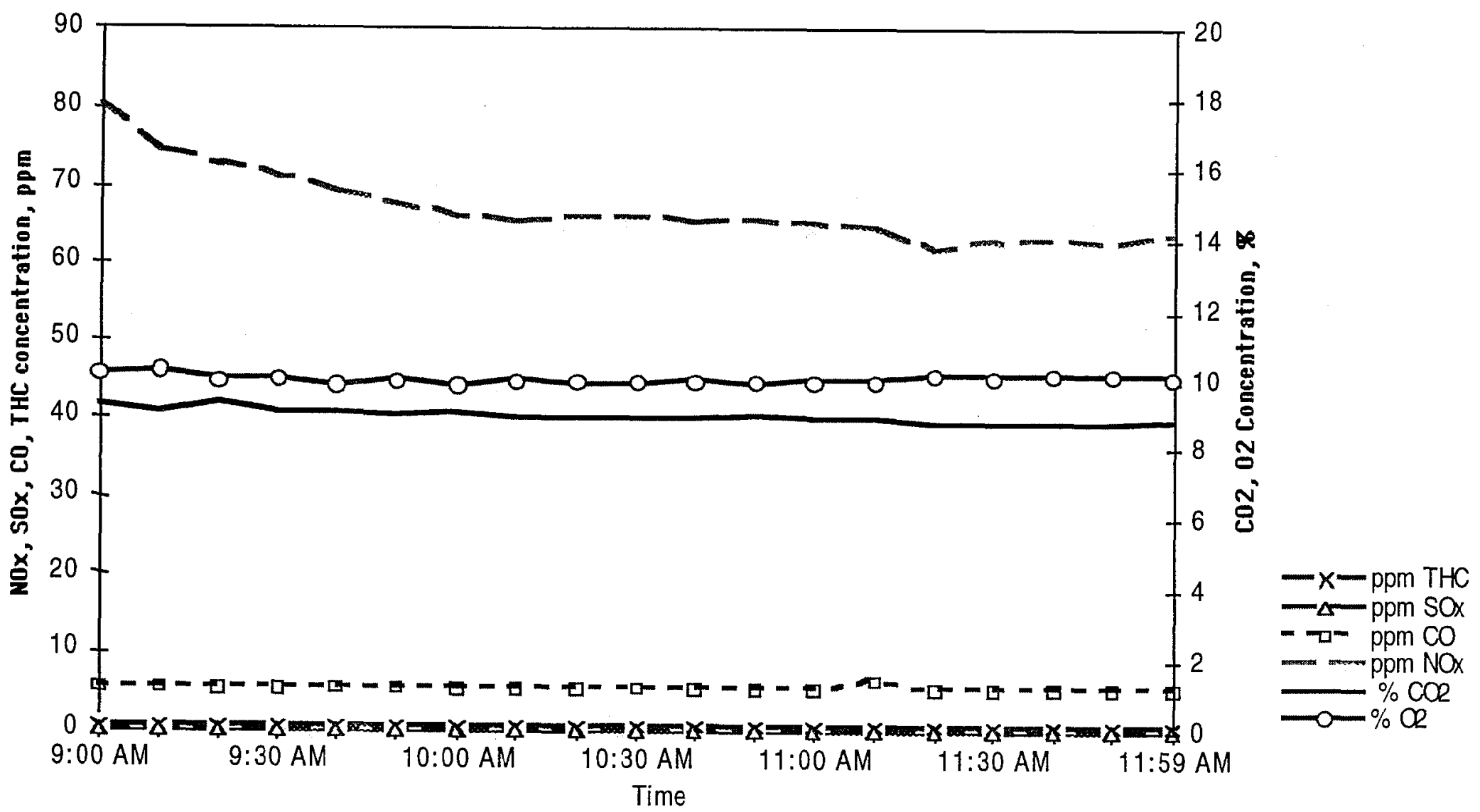

Fig. 5 Concentrations of off-gas species during the $8 \mathrm{hr}$ test with Toluene [Toluene feed at $1.2 \mathrm{~kg} / \mathrm{hr}, 30 \%$ excess air, salt at $950^{\circ} \mathrm{C}(8 \mathrm{hrs} \mathrm{run})$ 


\section{Table III: $\quad$ Elemental Composition of EDU Spent Salt}

\begin{tabular}{|c|c|c|c|}
\hline Element & Composition, wt\% & Element & Composition, wt\% \\
\hline $\mathrm{C}$ & 0.99 & 0 & 1.98 \\
\hline $\mathrm{Na}$ & 38.69 & $\mathrm{Si}$ & 0.04 \\
\hline $\mathrm{P}$ & 0.01 & $\mathrm{~S}$ & 0.08 \\
\hline $\mathrm{Cl}$ & 57.54 & $\mathrm{~K}$ & 0.01 \\
\hline $\mathrm{V}$ & 0.014 & $\mathrm{Cr}$ & 0.48 \\
\hline $\mathrm{Mn}$ & 0.03 & $\mathrm{Fe}$ & 0.04 \\
\hline $\mathrm{Ni}$ & 0.04 & $\mathrm{Cu}$ & 0.03 \\
\hline $\mathrm{Br}$ & 0.00 & $\mathrm{Mo}$ & 0.02 \\
\hline $\mathrm{Pt}$ & 0.01 & & \\
\hline
\end{tabular}

Table III indicates that the spent salt contains about $95 \mathrm{wt} \%$ sodium chloride along with minor amounts of several metals. Many of the metals present are at levels exceeding the U.S. Environmental Protection Agency land-ban criteria (RCRA) and this salt would be considered a hazardous waste if disposed of without further clean-up.

The spent salt was then dissolved into water and solution samples were taken for colorimetric analyses at various times after the primary metal precipitation and then again after the secondary metal precipitation step. Table IV shows these results. Concentrations of soluble metal species in the salt solution after the primary metal precipitation step , except $\mathrm{Cr}^{6+}$, are very low due to their low solubilities in water. Further removal of chromate ion $\mathrm{Cr}^{6+}$ is achieved in the secondary metal precipitation step by adding dithionite.

$$
2 \mathrm{CrO}_{4}{ }^{2-}+\mathrm{S}_{2} \mathrm{O}_{4}{ }^{2-}(\text { excess })+4 \mathrm{H}_{2} \mathrm{O}-->2 \mathrm{Cr}(\mathrm{OH})_{3}+2 \mathrm{SO}_{4}^{2-}+2 \mathrm{OH}^{-}
$$


Table IV Concentration of Soluble Species in Salt Solution

\begin{tabular}{|l|c|c|c|c|c|}
\hline & \multicolumn{5}{|c|}{ Concentrations, ppm } \\
Species & $1 \mathrm{hr}$ & \multicolumn{2}{c}{$\begin{array}{c}\text { 22 hrs } \\
\text { After Cr } \\
\text { Removal }\end{array}$} \\
\hline $\mathrm{Cl}^{-}$ & 120,000 & & & & 120,000 \\
\hline $\mathrm{Fe}^{+2} / \mathrm{Fe}^{+3}$ & 21.0 & 5.0 & 6.5 & & 2.8 \\
\hline $\mathrm{Ni}^{+2}$ & 45.0 & 9.7 & 9.5 & & 2.0 \\
\hline $\mathrm{Cr}^{+6}$ & 540.0 & 560.0 & 525.0 & & 0.5 \\
\hline $\mathrm{Mn}^{+2}$ & & 17.4 & 17.5 & & 20.6 \\
\hline $\mathrm{SiO}_{2}$ & & 340.0 & 350.0 & & 60.0 \\
\hline $\mathrm{SO}_{4}{ }^{-2}$ & & & 200.0 & & 2600.0 \\
\hline $\mathrm{Cu}^{+2}$ & & & & 6.4 & 0.5 \\
\hline $\mathrm{Zn}^{+2}$ & & & & 1.3 & 0.5 \\
\hline $\mathrm{Mo}^{+6}$ & & & & 131.0 & 46.0 \\
\hline $\mathrm{PO}_{4}^{-3}$ & & & & 5.5 & 0.5 \\
\hline $\mathrm{NO}_{3}^{-}$ & & & & 4.6 & 16.4 \\
\hline
\end{tabular}

*Dithionite was added a week after dissolving the salt.

Chromium hydroxide, a green gelatin-like solid, precipitated as a result of the reaction. With an excess of dithionite, the concentration of $\mathrm{Cr}^{6+}$ dropped to $<1 \mathrm{ppm}$ from $>500 \mathrm{ppm}$, indicating that dithionite is an excellent reagent for removing chromium from the solution. Table IV also shows that sulfate ions in the solution, a benign species which should not be a concern, increased from $200 \mathrm{ppm}$ to $2600 \mathrm{ppm}$ after the secondary metal precipitation step.

Table V shows the concentrations of several key metal species after completion of the clean-up process. It indicates that very clean dry salt can be achieved after the process; concentrations of metal species in the salt are mostly less than $100 \mathrm{ppm}$, some are in ppm.

Radionuclides Removal From MSO Spent Salts

If waste feed which contains radionuclides is processed by MSO, the radionuclides will be captured and held in the salt. Most radioactive compounds would co-precipitate with ash/mineral residue and be removed from the salt solution after the dissolution and first filtration step. Some radionuclides, such as thorium and uranium, will form complex ions and stay in the solution. A process to remove uranium and thorium from salt solutions has been developed by our group. This process includes $\mathrm{pH}$ adjustment, chemical reduction, and ion exchange. It has been successfully demonstrated in lab scale experiments $[7,8,9,10]$. 
Table V: Concentrations of Key Metal Species in Cleaned Salt (ppm)

\begin{tabular}{|l|c|c|}
\hline Species & In solution & Dry salt residue \\
\hline $\mathrm{Fe}$ & 2.8 & 13.9 \\
\hline $\mathrm{Ni}$ & 2.0 & 9.9 \\
\hline $\mathrm{Mn}$ & 20.6 & 102.0 \\
\hline $\mathrm{Cu}$ & 0.5 & 2.5 \\
\hline $\mathrm{Zn}$ & 0.5 & 2.5 \\
\hline $\mathrm{Cr}$ & 0.5 & 2.5 \\
\hline $\mathrm{Mo}$ & 46.0 & 228.0 \\
\hline $\mathrm{As}{ }^{*}$ & 0.5 & 2.5 \\
\hline $\mathrm{Se}^{*}$ & 0.9 & 4.5 \\
\hline $\mathrm{Ba}^{*}$ & 0.04 & 0.2 \\
\hline $\mathrm{Be}^{*}$ & $\mathrm{ND}$ & $\mathrm{ND}$ \\
\hline $\mathrm{Cd}^{*}$ & $\mathrm{ND}$ & $\mathrm{ND}$ \\
\hline $\mathrm{Pb}^{*}$ & $\mathrm{ND}$ & $\mathrm{ND}$ \\
\hline $\mathrm{Ag}^{*}$ & $\mathrm{ND}$ & $\mathrm{ND}$ \\
\hline $\mathrm{V}^{*}$ & $\mathrm{ND}$ & $\mathrm{ND}$ \\
\hline $\mathrm{Ca}^{*}$ & $\mathrm{ND}$ & $\mathrm{ND}$ \\
\hline $\mathrm{Tl}^{*}$ & $\mathrm{ND}$ & $\mathrm{ND}$ \\
\hline
\end{tabular}

*ICP/MS measurement

Final Forms

Our ceramic final forms recipes are designed to achieve maximum loading of the inorganic residue into the ceramic, while not exceeding the solid solubility of the minor and trace elements in their host mineral phases or producing less than $\sim 10 \mathrm{wt} \%$ of any of the design host phases. The latter requirement ensures a dominant phase assemblage in the presence of the large variety of constituents. A typical recipe is given in Table VI. For a typical "combustible" waste stream (e.g., laboratory waste such as paper, gloves, booties, etc.), waste loading is limited to about $40 \%$ by the silica, alumina and magnesia in the incoming waste stream. Waste loading may be further constrained by silica introduced during salt recycling.

Using bench-scale equipment, we have fabricated over 250 experimental ceramics under a range of processing conditions and containing a wide variety of elements - as many as 46 elements, including 15 of the 18 having leach limits assigned by U.S. or California regulations, in a single formulation. The purposes of these experiments were to investigate the phase formation, microstructure, partitioning, leach behavior, and processing. The resulting materials are rather complex, and interpreting their properties is not simple.

Experimental specimens were characterized by gravimetry (porosity), liquid-intrusion porosimetry (connected porosity), SEM-EDS (microstructure, phase compositions), X-ray diffraction (phase identification), X-ray fluorescence (overall composition, volatility losses), electron microprobe (partitioning), and SIMS (partitioning). A small amount of STEM analysis also has been performed. Trapped volatiles are analyzed with ICP-OES. Leachate analysis is by ICP-OES and ICP-MS. A typical SEM microstructure is shown in Fig. 7. 
Table VI. Typical surrogate residue recipe (No. 75).

\begin{tabular}{|c|c|c|c|}
\hline Compound & Weight (g) & Compound & Weight (g) \\
\hline $\mathrm{Al}(\mathrm{OH}) 3$ & 31.73 & $\mathrm{AgNO}_{3}$ & 3.0 \\
\hline $\mathrm{Al}_{2} \mathrm{O}_{3} \cdot 2 \mathrm{SiO}_{2} \cdot 2 \mathrm{H}_{2} \mathrm{O}$ & 32.00 & $\mathrm{Ga}_{2} \mathrm{O}_{3}$ & 0.1 \\
\hline $\mathrm{TiO}_{2}$ & 17.42 & $\mathrm{CdO}$ & 0.1 \\
\hline $\mathrm{Zr}\left(\mathrm{NO}_{3}\right)_{4} \cdot 5 \mathrm{H}_{2} \mathrm{O}$ & 14.84 & $\mathrm{Sb}_{2} \mathrm{O}_{3}$ & 0.20 \\
\hline $\mathrm{NaOH}$ & 9.02 & $\mathrm{Tl}_{2} \mathrm{O}_{3}$ & 2.0 \\
\hline $\mathrm{KOH}$ & 1.04 & $\mathrm{~Pb}_{2} \mathrm{O}_{3}$ & 0.1 \\
\hline $\mathrm{MgO}$ & 6.57 & $\mathrm{MoO}_{3}$ & 0.1 \\
\hline $\mathrm{CaO}$ & 9.24 & $\mathrm{Ce}_{2} \mathrm{O}_{3}$ & 0.1 \\
\hline $\mathrm{SrO}$ & 0.1 & $\mathrm{Nd}_{2} \mathrm{O}_{3}$ & 0.1 \\
\hline $\mathrm{BaO}$ & 0.12 & $\mathrm{UO}_{2}\left(\mathrm{NO}_{3}\right) 3 \cdot 6 \mathrm{H}_{2} \mathrm{O}$ & 2.0 \\
\hline $\mathrm{ZnO}$ & 3.29 & $\mathrm{Gd}\left(\mathrm{NO}_{3}\right)_{3} \cdot 6 \mathrm{H}_{2} \mathrm{O}$ & 0.2 \\
\hline $\mathrm{V}_{2} \mathrm{O}_{3}$ & 0.1 & $\mathrm{BeC}_{2} \mathrm{O}_{4} \cdot 3 \mathrm{H}_{2} \mathrm{O}$ & 6.0 \\
\hline $\mathrm{Cr}_{2} \mathrm{O}_{3}$ & 0.1 & \multirow{2}{*}{\multicolumn{2}{|c|}{$\begin{array}{l}\text { Calculated ceramic yield: } 100 \mathrm{~g} \\
\text { Calculated phase composition: }\end{array}$}} \\
\hline $\mathrm{MnO}$ & 0.1 & & \\
\hline $\mathrm{Fe}_{2} \mathrm{O}_{3}$ & 1.41 & nepheline & $35.5 w t \%$ \\
\hline $\mathrm{CoO}$ & 0.1 & spinel & 31.0 \\
\hline $\mathrm{NiO}$ & 0.1 & zirconolite & 11.9 \\
\hline $\mathrm{CuO}$ & 0.1 & perovskite & 11.7 \\
\hline $\mathrm{NH}_{4} \mathrm{H}_{2} \mathrm{PO}_{4}$ & 3.12 & rutile & 5.2 \\
\hline $\mathrm{B}_{2} \mathrm{O}_{3}$ & 0.17 & apatite & 4.5 \\
\hline
\end{tabular}




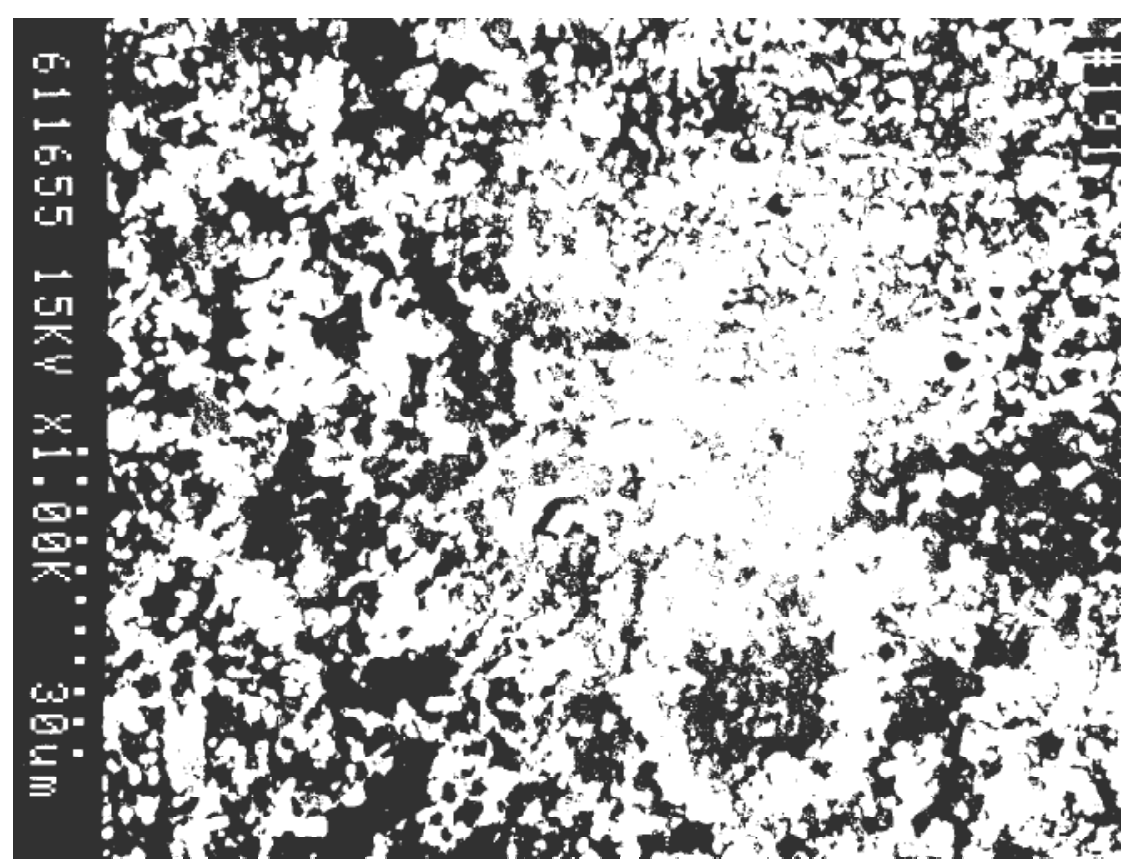

Figure 7. Microstructure of a typical experimental ceramic waste form (size bar $=30 \mu \mathrm{m})$.

The specimen of Fig. 7 (No. 19) was sintered at $1150^{\circ} \mathrm{C}$ for $24 \mathrm{~h}$ to coarsen the structure for characterization purposes. Grain size for normal (1-h) sintering is smaller but otherwise similar. The phases have the following appearance: The white equiaxed grains are zirconolite; the lightgray equiaxed grains are perovskite; the darker-gray elongated grains are spinel; and the darkest gray regions are nepheline. In addition to the fine-scale porosity visible here (black), views of this specimen at lower magnifications showed some very large round pores presumable resulting from gas evolution.

The U.S. Environmental Protection Agency has prescribed the Toxicity Characteristic Leaching Procedure (TCLP) [13] as the test for determining whether a waste is to be classified as chemically toxic. The original leachate concentration standards are known as the "Regulatory Limits." Under certain situations, the TCLP leachate must now also satisfy the "Universal Treatment Standards" (UTS) [14,15] concentration limits. We have scaled the TCLP test down from the specified minimum of sample (100 g) to our pellet size (1-3 g), keeping the solution-towaste ratio and other parameters as specified. Additionally, our ceramic is currently subject to California's "Waste Extraction Test" (WET), which is more stringent.

The results for a recent sample of our ceramic (a replicate of No. 191, from recipe No. 75) are shown in Table VII. As can be seen, this sample easily passed the original TCLP limits and failed the UTS limits only for $\mathrm{Pb}$ and (barely) $\mathrm{V}$. We have evidence that at least some of the $\mathrm{Pb}$ and $\mathrm{V}$ reside in the glass phase, and anticipate that future efforts to minimize residual glass will reduce the release of these elements. 
Table VII. TCLP leaching of a complex final form ceramic.

\begin{tabular}{|l|l|c|c|l|}
\hline \multirow{2}{*}{ Element } & $\begin{array}{l}\text { Pellet } \\
\text { conc. }\end{array}$ & $\begin{array}{c}\text { Specimen } \\
\text { Leachate } \\
\text { conc. }\end{array}$ & $\begin{array}{c}\text { Regulatory } \\
\text { Limit }\end{array}$ & UTS \\
\cline { 2 - 5 } & wt \% & ppm & ppm & ppm \\
\hline $\mathrm{Hg}$ & 0 & & 0.2 & 0.025 \\
$\mathrm{Be}$ & 0.36 & $\sim 0.010$ & & 0.014 \\
$\mathrm{Cd}$ & 0.088 & 0.03 & 1.0 & 0.19 \\
$\mathrm{Se}$ & 0 & & 1.0 & 0.16 \\
$\mathrm{As}$ & 0 & & 5.0 & 5.0 \\
\hline $\mathrm{Cr}(3+$, tot $)$ & 0.068 & $<0.05$ & 5.0 & 0.86 \\
$\mathrm{~Pb}$ & 0.082 & 1.33 & 5.0 & 0.37 \\
$\mathrm{Ag}$ & 1.90 & 0.06 & 5.0 & 0.30 \\
$\mathrm{TI}$ & $(1.79)$ & 0.02 & & 0.078 \\
$\mathrm{Sb}$ & 0 & $<0.1$ & & 2.1 \\
\hline $\mathrm{Ni}$ & 0 & $<0.08$ & & 5.0 \\
$\mathrm{~V}$ & 0.68 & 0.24 & & 0.23 \\
$\mathrm{Ba}$ & 0.090 & 5.3 & 100. & 7.6 \\
$\mathrm{Zn}$ & 2.64 & 0.81 & & 5.3 \\
$\mathrm{U}$ & 0.84 & $<0.03$ & & \\
\hline
\end{tabular}

Since the principal focus of this paper has been on the MSO process and the associated salt recycle, for further details of ceramic final forms process design and results, the reader is referred to references 11 and 12 .

\section{CONCLUDING REMARKS}

A MSO engineering demonstration unit, EDU, has been run successfully with several model feeds with very high process efficiency. We also have developed a process to clean up MSO spent salts. This process can treat various types of spent salts, and we have demonstrated it in the lab on a spent salt from EDU, which had a high chloride but low ash content. The results show that most metals precipitate out during the dissolution process. Further removal of metals, such as, chromium, thorium, and uranium can be accomplished in the subsequent steps. Futhermore, we have demonstrated the bench-scale fabrication of a polyphase ceramic final waste form designed to immobilize the mineral residues of the MSO system. Individual samples of the ceramic have been made containing as many as 46 chemical elements, including 15 of the 18 regulated ones. Resistance to leaching of regulated elements is generally excellent. In one very complex formulation, only Pb seriously failed the federal UTS limit. This failure may well be eliminated by reducing the amounts of residual glass and porosity in the ceramic. Efforts will be made to satisfy California requirements as they become more certain.

An integrated MSO pilot scale facility that includes Salt Recycle has also been designed and built. This facility is now fully operational. Treatability studies will be conducted in the LLNL facility with real mixed wastes during Fiscal Year 1998. With knowledge and experience gained from this facility, treatment of a variety of DOE mixed wastes and private-sector hazardous wastes should be possible. 


\section{ACKNOWLEDGEMENTS}

The authors wish to thank the following people who contributed to this work: Bill Brummond, Paul Curtis, George Goers, Frank Silva, Gregg Soto, Leslie Summers, Richard Van Konynenburg, Erica von Holtz, and Dwight Squire, Francis Wang. This work was performed under the auspices of the U.S. Department of Energy by the Lawrence Livermore National Laboratory under contract number W-7405-ENG-48. Funding was provided by DOE/EM's Office of Waste Management (EM-30). 


\section{REFERENCES}

1. L. Abbey, M. McDowell, A. Darnell, R. Gay, K. Knudsen, and C. Newman, "Final Report for Molten Salt Oxidation of RMDF Mixed Wastes," 022-TR-0002, ETEC, Rockwell International, Canoga Park, Ca, October 1993.

2. M.G. Adamson, Z. Chiba, E.H. von Holtz, and R.D. Streit, "Development of Advanced Waste Treatment Technologies for Demonstration in the Mixed Waste Treatment Facility," Proceedings of the 3rd Biennial Mixed Waste Symposium, Baltimore, Maryland, August 7-10, 1995.

3. J. C. Rudolph, et al., "Molten Salt Oxidation of Chloro-organic Compounds: Experimental Results for Product Gas Compositions and Final Forms Studies," ORNL/TM-12941, Oak Ridge National Laboratory, Oak Ridge, TN, April 1995.

4. R.S. Upadhye, W.A. Brummond, C.O. Pruneda, "Destruction of High Explosives and Wastes Containing High Explosives Using the Molten Salt Destruction Process," UCRL-JC-109564, Lawrence Livermore National Laboratory, Livermore, CA, May 1992.

5. Peter C. Hsu, Erica H. von Holtz, David Hipple, Leslie Summers, Francis Wang, and Martyn Adamson ,"MSO Spent Salt Clean-Up/Recovery Process," unpublished LLNL report, February 1997.

6. D. W. Stevens, et al., "Microstructure and Kinetics of Hot Corrosion for a Nickel Alloy in Molten Salt," UCRL-JC-126053, Lawrence Livermore National Laboratory, Livermore, CA, December 1996.

7. Peter C. Hsu, Erica H. von Holtz, David Hipple, Leslie Summers, and William A. Brummond, "Spent Salt Clean-Up/Recovery Process Development For Molten Salt Oxidation," a pending patent, LLNL Docket No. IL-9978, June 1996.

8. P. C. Hsu, D. A. Jones, D. L. Hipple, E. H. von Holtz, and Martyn Adamson "Process Modeling of Salt Recycle with EQ 3/6", LLNL report in preparation.

9. P. C. Hsu, L. Summer, E.H. von Holtz, D. Hipple, and Martyn Adamson "Uranium Removal in the Spent Salt Cleanup Process for Molten Salt Oxidation, presented at the AIChE Spring National Meeting, Houston, March 1997.

10. Peter C. Hsu, Erica H. von Holtz, David Hipple, Leslie Summers, and Martyn Adamson, "Uranium and Thorium Removal from MSO Spent Salts," a pending patent, DOE Case No. S86,788 (RL-13,907), LLNL Docket No. IL-10145, May 1997

11. R. A. Van Konynenburg, R. W. Hopper, J. A. Rard, F. J. Ryerson, D. L. Phinney, L. D. Hutcheon and P. G. Curtis, "Ceramic Waste Form for Residues from Molten Salt Oxidation of Mixed Waste," in Scientific Basis for Nuclear Waste Management XIX, edited by Dieter Knecht \& William M. Murphy (Materials Research Society, Symposium Proceedings 412, Pittsburgh, 1996) pp. 321-328.

12. P. C. Hsu, et al., "Integrated Demonstration of Molten Salt Oxidation with Salt Recycle for Mixed Waste Treatment," Proceedings of Waste Management 98, Tucson, Arizona, March 1-5, 1998.

13. U.S. Environmental Protection Agency, Method 1311 Toxicity Characteristic Leaching Procedure, 40 CFR Part 261.24 and Appendix II, U.S. Code of Federal Regulations, U.S. Govt. Printing Office, Washington, D.C. 
14. U. S. Environmental Protection Agency, 40 CFR Parts 148, 260, 261, 264, 265, 266, 268 , and 271: Land Disposal Restrictions Phase II--Universal Treatment Standards, and Treatment Standards for Organic Toxicity Characteristic Wastes and Newly Listed Wastes, Final Rule, Federal Register Vol. 59, No. 180 (September 19, 1994), p. 47982.

15. U.S. Environmental Protection Agency, 40 CFR Parts 148, 268, and 271 Land Disposal Regulations--Phase IV: Issues Associated with Clean Water Act Treatment Equivalency, and Treatment Standards for Wood Preserving Wastes and Toxicity Characteristic Metal Wastes, Proposed Rule, Federal Register Vol. 60, No. 162 (August 22, 1995), p. 43654. 


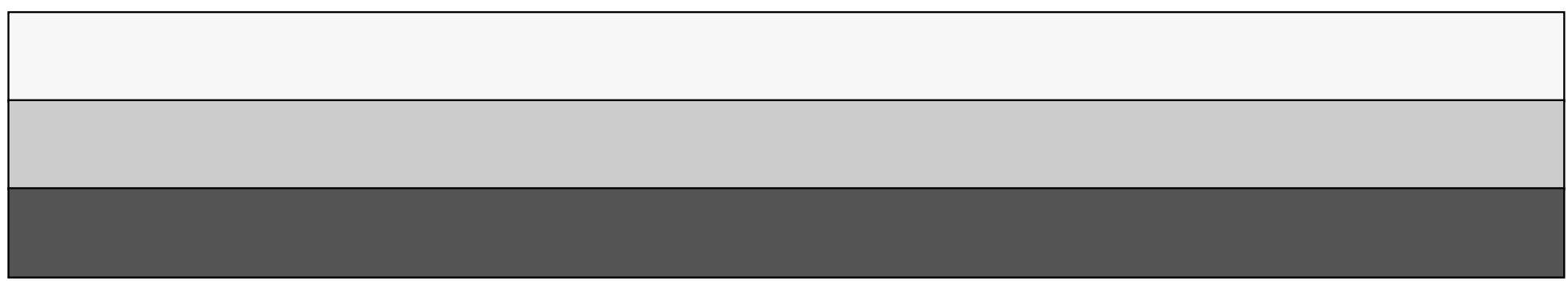

